Aim of the study: Data are available indicating that red blood cell distribution width (RDW) is higher in cancer patients compared to healthy individuals or benign events. In our study, we aimed to investigate the influence of different RDW levels on survival in lung cancer patients.

Material and methods: Clinical and laboratory data from 146 patients with lung cancer and 40 healthy subjects were retrospectively studied. RDW was recorded before the application of any treatment. Patients were categorised according to four different RDW cut-off values (median RDW, RDW determined by ROC curve analysis, the upper limit at the automatic blood count device, and RDW cut of value which used in previous studies). Kaplan-Meier survival analysis was used to examine the effect of RDW on survival for each cut-off level.

Results: The median age of patients was 56.5 years (range: $26-83$ years). The difference in median RDW between patients and the control group was statistically significant (14.0 and 13.8 , respectively, $p=0.04$ ). There was no difference with regard to overall survival when patients with RDW $\geq 14.0$ were compared to those with RDW < 14.0 ( $p=0.70)$; however, overall survival was 3.0 months shorter in low values of its own group in each of the following cut-off values: $\geq 14.2$ $(p=0.34), \geq 14.5(p=0.25), \geq 15$ $(p=0.59)$, although no results were statistically significant.

Discussion: We consider that the difference between low and high RDW values according to certain cut-off values may reflect the statistics of larger studies although there is a statistically negative correlation between RDW level and survival.

Key words: prognosis, lung cancer, blood, RDW.

Contemp Oncol (Pozn) 2016; 20 (2): 153-157 DOI: $10.5114 /$ wo.2016.60072

\section{Evaluation of the effects of red blood cell distribution width on survival in lung cancer patients}

\author{
Mehmet Kos ${ }^{1}$, Cemil Hocazade², F. Tugba Kos ${ }^{3}$, Dogan Uncu², Esra Karakas², \\ Mutlu Dogan'2, Hikmet G. Uncu', Nuriye Ozdemir ${ }^{2}$, Nurullah Zengin ${ }^{2}$ \\ ${ }^{1}$ Department of Internal Medicine, Faculty of Medicine, Duzce University, Duzce, Turkey \\ ${ }^{2}$ Department of Medical Oncology, Ankara Numune Education and Research Hospital, \\ Ankara, Turkey \\ ${ }^{3}$ Department of Medical Oncology, Faculty of Medicine, Duzce University, Duzce, Turkey \\ ${ }^{4}$ Turkish Drug \& Medical Device Institution, Turkey
}

\section{Introduction}

Lung cancer is the most common fatal cancer type [1]. Local recurrence or distant metastasis develops in approximately $40 \%$ of these patients despite treatments, even if at an early stage [2]. Most of the non-small cell lung cancer (NSCLC) patients have metastasis at the time of diagnosis. Treatment of stage IV disease is palliative chemotherapy [3]. However, objective response is possible in only $30 \%$ of the patients who receive chemotherapy. Five-year survival is approximately $15 \%$, despite advancements in diagnosis and treatment [4]. Therefore, determining the influence of factors on overall survival is important.

Red blood cell distribution width (RDW) is a parameter that quantitatively reflects the change in sizes of circulating erythrocytes [5]. It is routinely used for discrimination of different anaemia types. The influence of chronic inflammation in the development and progression of cancers has been emphasised in many studies [6, 7]. In recent years, RDW has also been evaluated as a haematological and inflammatory parameter, and elevated RDW has been shown to be accompanied by all cause of mortality including cancer-related deaths and chronic lower respiratory tract infection-related deaths, besides increased risk for cardiovascular mortality [8, 9].

There are a limited number of studies investigating whether RDW is a factor determining mortality risk in lung cancer [10, 11]. Therefore, we planned to investigate the influence of different RDW levels in lung cancer in our study.

\section{Material and methods}

In our study, patients with a confirmed diagnosis of NSCLC histopathologically followed-up at our in medical oncology clinic between 2005 and 2011 were included. The clinicopathological characteristics, laboratory data, and treatment data of the patients were obtained by screening the hospital automation system and file archive system retrospectively. All patients were classified as stage I to stage IV, according to the guidelines of the tumour-node-metastasis (TNM) staging system of the Union for International Cancer Control ( $7^{\text {th }}$ edition). Retrospective data of forty healthy subjects who were admitted to outpatient clinics for general control purposes were included in the study and RDW values of healthy control subjects were compared with the values of the patients. Any subjects who had additional diseases, especially anaemia, thyroid dysfunction, or lung cancer, and those who were using medicines that might affect RDW were excluded. The lymphocyte and platelet levels of patients before receiving any treatment, according to the 
stage, were recorded. RDWs were analysed with an automated haematology analyser (Coulter Hmx; Beckman Coulter (UK) Ltd., High Wycombe, Bucks, UK). The reference range was $11.5 \%$ to $14.5 \%$. Patients were categorised according to four different RDW cut-off values (median RDW, RDW value determined by ROC curve analysis, the upper limit at the automatic blood count device for RDW, and RDW cut-off value used in previous studies). Patients whose file information was missing or inaccessible were excluded. The current state of the patients was learned from hospital records or by calling the patients.

\section{Statistical analysis}

All statistical analyses were performed using the Statistical Package for the Social Sciences software program version 15.0 (SPSS Inc., Chicago, IL, USA). Chi-square or Fisher exact tests were used for comparative analysis of categorical data. A receiver operator characteristic (ROC) curve was used for assessment, e.g. the association between RDW and survival. The duration of overall survival (OS) was calculated from the date of pathologic diagnosis until death or until the date of the last follow-up visit. Overall survival was estimated using the Kaplan-Meier method, and the log-rank test was used for comparison of outcomes. A p-value < 0.05 was considered statistically significant.

Table 1. General characteristics of all patients $(n=146)$

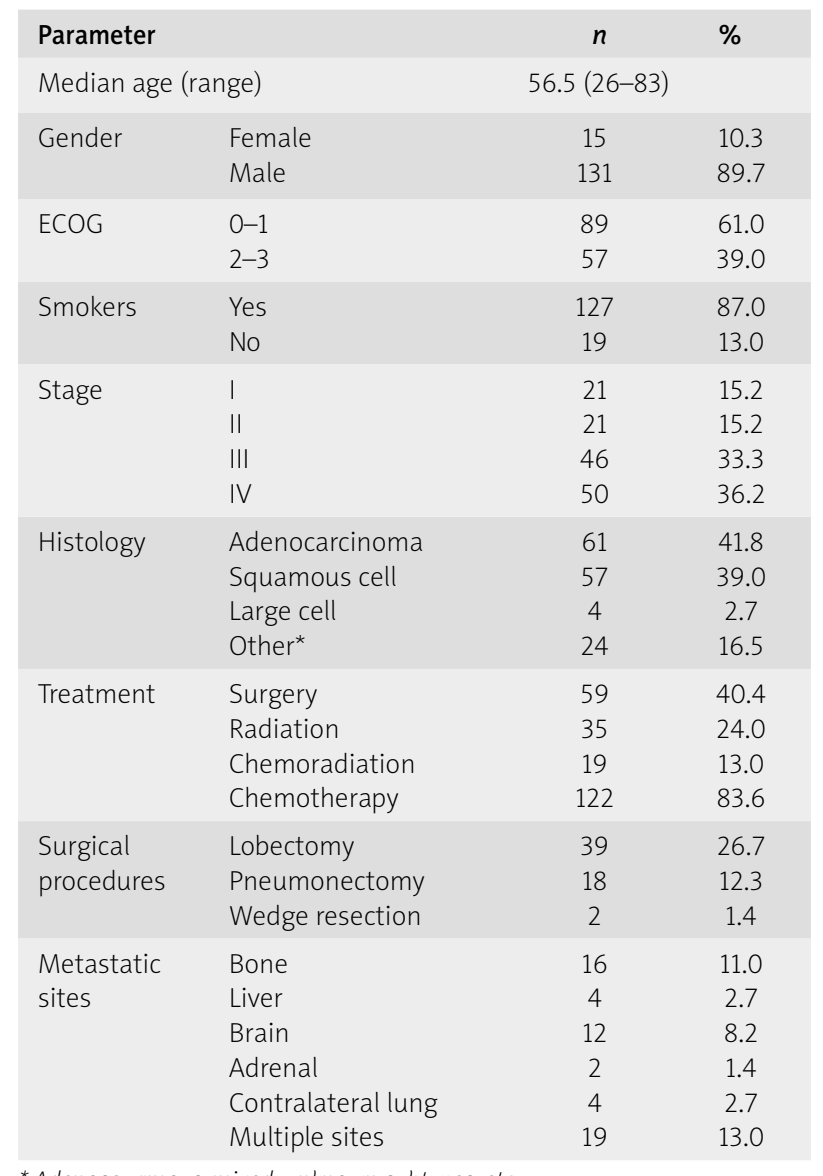

${ }^{*}$ Adenosquamous, mixed, unknown subtypes, etc.

\section{Results}

One hundred and forty-six patients were included in the study, whose entire set of parameters could be obtained. The median age of patients was 56.5 years (range: 26-83 years). One hundred and thirty-one patients (89.7\%) were male. Fifty (36.2\%) patients had metastasis at diagnosis. Adenocarcinoma $(n=61,41.8 \%)$ and squamous cell carcinoma ( $n=57,39.0 \%$ ) were the most frequent histological subtypes. The general characteristics of the patients are shown in Table 1. The median age of the healthy control group was 56.0 years (range: $30-78$ years). There was no significant difference for median age between patients and the control group $(p=0.92)$. Thirty-two healthy subjects (80.0\%) were male and eight were female (20.0\%). There was no difference in gender proportion between patients and the control group $(p=0.11)$. Twenty-two control subjects (55.0\%) were smokers, and the difference between the groups was statistically significant $(p<0.0001)$. The median RDW in the healthy control group was 13.8 years (range: $12.8-16.4$ years). The difference for median RDW between patients and the control group was statistically significant $(p=0.04)$.

Patients were categorised according to four different RDW cut-off values. The median RDW value of 14.0 was used for the first classification. The group with RDW $<14.0$ consisted of 62 patients (42.5\%), and the group with RDW $\geq 14.0$ consisted of 84 patients (57.5\%). ROC curve analysis was used to determine the best value for overall survival for the second categorisation. Area under the curve (AUC) 0.565 (95\% Cl [confidence interval]: 0.453-0.676) was calculated according to this; the value of 14.2 was taken as the cut-off value of the second categorisation with $48 \%$ sensitivity and 64\% specificity (Fig. 1). The RDW $<14.2$ group consisted of 80 patients (54.8\%) and the RDW $\geq 14.2$ group consisted of 66 patients (45.2\%). For the third categorisation, the upper limit on the automatic blood count device was used. The RDW $<14.5$ group consisted of 87 patients $(59.6 \%)$ and the RDW $\geq 14.5$ group consisted of 59 patients (40.4\%). The value used in previous studies, 15 , was taken for the final categorisation $[10,12]$. The RDW $<15.0$ group consisted of 92 patients (63.0\%), and the RDW $\geq 14.0$ group consisted of 54 patients (37.0\%).

There was not a difference between low and high values of the patients in Group 1 and Group 2 with regard to general characteristics. Of the patients in Group 3 and Group 4, the ones with low values were in earlier stages compared to the ones with high values and this difference was significant $(p=0.05)$, there was not a difference between low and high values with regard to other characteristics (Table 2).

In Group 1, median overall survival was estimated as 18 (95\% Cl: 6.4-12.7) months for the patients with RDW $<14.0$ and 18.0 (95\% Cl: 12.7-23.3) months for the patients with RDW $\geq 14.0(p=0.70)$. In Group 2 , while median overall survival was estimated at 19.0 (95\% Cl: 8.1-29.9) months in patients with RDW $<14.2$, it was estimated at 16.0 (95\% Cl: 10.8-21.2) months in patients with RDW $\geq 14.2$; however, the difference was not statistically significant $(p=0.34)$. In Group 4, while median overall survival 
Table 2. General characteristics of patients according to RDW groups

\begin{tabular}{|c|c|c|c|c|c|c|c|c|c|c|c|c|}
\hline \multirow[t]{2}{*}{ Parameter } & \multicolumn{3}{|c|}{ Group 1} & \multicolumn{3}{|c|}{ Group 2} & \multicolumn{3}{|c|}{ Group 3} & \multicolumn{3}{|c|}{ Group 4} \\
\hline & $\begin{array}{c}<14 \\
(n=62) \\
n\end{array}$ & $\begin{array}{c}\geq 14 \\
(n=84) \\
n\end{array}$ & $p$ & $\begin{array}{c}<14.2 \\
(n=80) \\
n\end{array}$ & $\begin{array}{c}\geq 14.2 \\
(n=66) \\
n\end{array}$ & $p$ & $\begin{array}{c}<14.5 \\
(n=87) \\
n\end{array}$ & $\begin{array}{c}\geq 14.5 \\
(n=59) \\
n\end{array}$ & $p$ & $\begin{array}{c}<15 \\
(n=92) \\
n\end{array}$ & $\begin{array}{c}\geq 15 \\
(n=54) \\
n\end{array}$ & $p$ \\
\hline $\begin{array}{l}\text { Age* }^{*} \\
<57 \\
\geq 57\end{array}$ & $\begin{array}{l}32 \\
30\end{array}$ & $\begin{array}{l}41 \\
43\end{array}$ & 0.86 & $\begin{array}{l}39 \\
41\end{array}$ & $\begin{array}{l}34 \\
32\end{array}$ & 0.87 & $\begin{array}{l}45 \\
42\end{array}$ & $\begin{array}{l}28 \\
31\end{array}$ & 0.74 & $\begin{array}{l}46 \\
46\end{array}$ & $\begin{array}{l}27 \\
27\end{array}$ & 1.00 \\
\hline $\begin{array}{l}\text { Gender } \\
\text { Female } \\
\text { Male }\end{array}$ & $\begin{array}{c}5 \\
57\end{array}$ & $\begin{array}{l}10 \\
74\end{array}$ & 0.58 & $\begin{array}{c}8 \\
72\end{array}$ & $\begin{array}{c}7 \\
59\end{array}$ & 0.90 & $\begin{array}{c}8 \\
79\end{array}$ & $\begin{array}{c}7 \\
52\end{array}$ & 0.59 & $\begin{array}{c}9 \\
83\end{array}$ & $\begin{array}{c}6 \\
48\end{array}$ & 0.78 \\
\hline $\begin{array}{c}\text { ECOG } \\
0-1 \\
2-3\end{array}$ & $\begin{array}{l}36 \\
50\end{array}$ & $\begin{array}{l}25 \\
32\end{array}$ & 0.86 & $\begin{array}{l}47 \\
32\end{array}$ & $\begin{array}{l}39 \\
25\end{array}$ & 0.86 & $\begin{array}{l}51 \\
34\end{array}$ & $\begin{array}{l}35 \\
23\end{array}$ & 0.96 & $\begin{array}{l}54 \\
36\end{array}$ & $\begin{array}{l}32 \\
21\end{array}$ & 0.96 \\
\hline $\begin{array}{c}\text { Stage } \\
\text { I-III } \\
\text { IV }\end{array}$ & $\begin{array}{l}40 \\
20\end{array}$ & $\begin{array}{l}48 \\
35\end{array}$ & 0.30 & $\begin{array}{l}53 \\
25\end{array}$ & $\begin{array}{l}35 \\
30\end{array}$ & 0.09 & $\begin{array}{l}58 \\
27\end{array}$ & $\begin{array}{l}30 \\
28\end{array}$ & 0.05 & $\begin{array}{l}62 \\
28\end{array}$ & $\begin{array}{l}28 \\
27\end{array}$ & 0.02 \\
\hline $\begin{array}{l}\text { Histology } \\
\text { Adenocarcinoma } \\
\text { Squamous cell } \\
\text { Other** }\end{array}$ & $\begin{array}{l}24 \\
23 \\
15\end{array}$ & $\begin{array}{l}37 \\
34 \\
13\end{array}$ & 0.41 & $\begin{array}{l}35 \\
30 \\
15\end{array}$ & $\begin{array}{l}26 \\
27 \\
13\end{array}$ & 0.86 & $\begin{array}{l}38 \\
31 \\
18\end{array}$ & $\begin{array}{l}23 \\
26 \\
10\end{array}$ & 0.58 & $\begin{array}{l}40 \\
33 \\
19\end{array}$ & $\begin{array}{c}21 \\
24 \\
9\end{array}$ & 0.58 \\
\hline $\begin{array}{l}\text { Treatment } \\
\text { Surgery } \\
\text { Radiation } \\
\text { Chemoradiation } \\
\text { Chemotherapy }\end{array}$ & $\begin{array}{l}55 \\
64 \\
73 \\
12\end{array}$ & $\begin{array}{l}29 \\
20 \\
11 \\
72\end{array}$ & $\begin{array}{l}0.12 \\
0.96 \\
0.97 \\
0.50\end{array}$ & $\begin{array}{l}44 \\
50 \\
59 \\
11\end{array}$ & $\begin{array}{c}22 \\
16 \\
7 \\
55\end{array}$ & $\begin{array}{l}0.13 \\
0.94 \\
0.47 \\
0.95\end{array}$ & $\begin{array}{l}39 \\
44 \\
53 \\
11\end{array}$ & $\begin{array}{c}20 \\
15 \\
6 \\
48\end{array}$ & $\begin{array}{l}0.23 \\
0.84 \\
0.46 \\
0.65\end{array}$ & $\begin{array}{c}36 \\
40 \\
49 \\
9\end{array}$ & $\begin{array}{c}18 \\
14 \\
5 \\
45\end{array}$ & $\begin{array}{l}0.22 \\
0.69 \\
0.44 \\
0.95\end{array}$ \\
\hline
\end{tabular}

*Age variable was categorised by median age as $<57$ and $\geq 57$ years

${ }^{* *}$ Adenosquamous, mixed, large cell, unknown subtypes, etc.

was 19.0 (95\% Cl: 8.7-29.3) months in patients with RDW $<15$, it was estimated at (95\% Cl: 11.0-21.0) months in patients with $\mathrm{RDW} \geq 15(p=0.25)$; however, the difference was not statistically significant ( $p=0.59)$ (Fig. 2).

\section{Discussion}

Studies are available revealing the association between RDW and mortality in benign conditions like heart failure and chronic obstructive pulmonary disease $[13,14]$. Data are also available indicating that RDW is higher in cancer patients compared to healthy individuals or in benign conditions [12, 15-17]. In a study conducted with symptomatic multiple myeloma patients, RDW value was categorised according to 14.5, the upper limit of reference value of the automated blood counter of the hospital. However, no difference was detected between the patients whose RDW was low $(\leq 14.5)$ and high (>14.5) with regard to overall survival $(p=0.236)$ [18]. Data are limited and conflicting about the association between RDW and overall survival in patients with solid cancers [10-12].

In a prospective study that aimed at comparing cancer patients and non-cancer patients with regard to RDW levels, cancer patients who had involuntary weight loss were shown to have higher RDW levels than those with non-cancer diseases ( $p=0.02$ ) [12]. However, in subgroup analysis done on 67 cancer patients, the influence of RDW on survival was investigated and a significant difference was not observed between dying and surviving patients after six months of follow-up with regard to RDW (median was taken as 15 for cut-off) ( $p=0.083$ ). In our study, al-

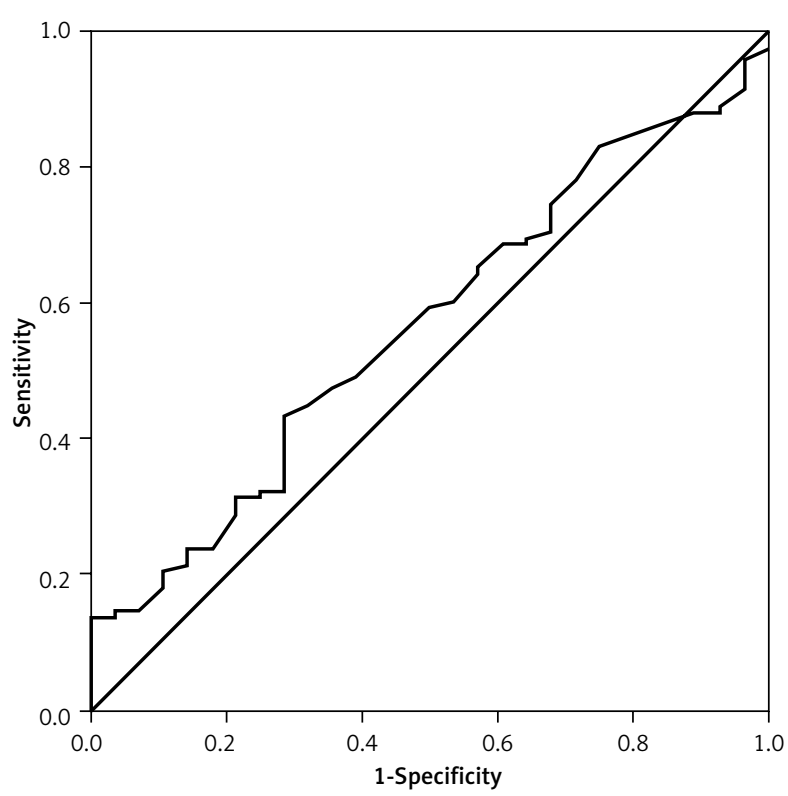

Fig. 1. The ROC curves for RDW

though a difference was detected between patients with low and high RDW levels with regard to three-month survival in groups 2, 3, and 4, this difference did not reach statistical significance. One of the two studies of the influence of RDW on survival in solid tumours was conducted on lung cancer patients. In that study, patients were classified according to upper limit of the automated blood count device in the hospital (RDW < 15 and $\geq 15$ ) [10]. In 

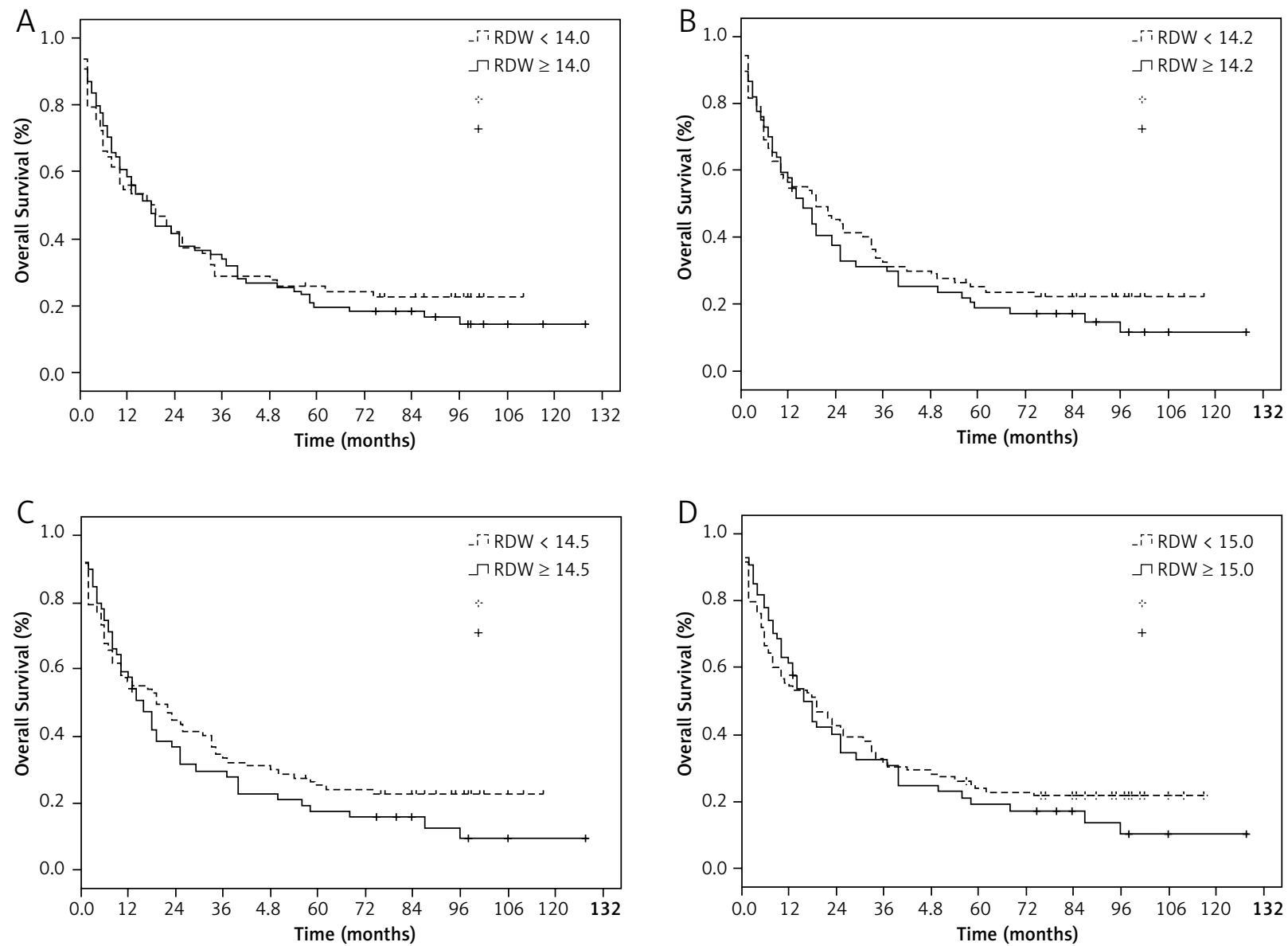

Fig. 2. Kaplan-Meier survival curves for overall survival of patients with Group 1 (A), Group 2 (B), Group 3 (C), and Group 4 (D)

the study, high RDW values were found to be related with poor prognosis $(p=0.002)$. Another large study was conducted by Warwick et al. in operated non-small cell lung cancer patients [11]. In the study, RDW levels were analysed by dividing subjects to four groups through graphics (Group $1<13.5$, Group 2 13.5-14.2, Group 3 14.2-15.3, and Group $>15.3)$. In that study, preoperative RDW > 15.3 was found to be related with mortality $(p<0.0001)$.

Our study is one of the few studies about the association between RDW and survival in solid tumours. In conclusion, although it is a statistically negative study about RDW level and survival, the difference between arms in Group 2 and Group 3 is striking in Kaplan-Meier curves. This suggests that the negative result is a reflection of the small number of patients.

The authors declare no conflict of interest.

\section{References}

1. Siegel R, Naishadham D, Jemal A. Cancer statistics. CA Cancer J Clin 2013; 63: 11-30.

2. Mountain CF. Revisions in the international system for staging lung cancer. Chest 1997; 111: 1710-7.
3. Ramalingam S, Belani C. Systemic chemotherapy for advanced nonsmall cell lung cancer: recent advances and future directions. Oncologist 2008; 13: 5-13.

4. Jemal A, Siegel R, Xu J, Ward E. Cancer statistics, 2010. CA Cancer J Clin 2010; 60: 277-300.

5. Förhécz Z, Gombos T, Borgulya G, Pozsonyi Z, Prohászka Z, Jánoskuti L. Red cell distribution width in heart failure: prediction of clinical events and relationship with markers of ineffective erythropoiesis, inflammation, renal function, and nutritional state. Am Heart J 2009; 158: 659-66.

6. Chiba T, Marusawa H, Ushijima T. Inflammation-associated cancer development in digestive organs: mechanisms and roles for genetic and epigenetic modulation. Gastroenterology 2012; 143: 550-63.

7. Mladenova D, Kohonen-Corish MR. Mouse models of inflammatory bowel disease insights into the mechanisms of inflammation-associated colorectal cancer. In Vivo 2012; 26: 627-46.

8. Patel KV, Semba RD, Ferrucci L, et al. Red cell distribution width and mortality in older adults: a meta-analysis. J Gerontol A Biol Sci Med Sci 2010; 65: 258-65.

9. Perlstein TS, Weuve J, Pfeffer MA, Beckman JA. Red blood cell distribution width and mortality risk in a community-based prospective cohort. Arch Intern Med 2009; 169: 588-94.

10. Koma Y, Onishi A, Matsuoka H, et al. Increased red blood distribution width associates with cancer stage and prognosis in patients with lung cancer. PLoS One 2013; 8: e80240.

11. Warwick R, Mediratta N, Shackcloth M, Shaw M, McShane J, Poullis M. Preoperative red cell distribution width in patients undergoing pulmonary resections for non-small-cell lung cancer. Eur J Cardiothorac Surg 2014; 45: 108-13. 
12. Baicus C, Caraiola S, Rimbas M, Patrascu R, Baicus A. Utility of routine hematological and inflammation parameters for the diagnosis of cancer in involuntary weight loss. J Investig Med 2011; 59: 951-5.

13. Felker GM, Allen LA, Pocock SJ, et al. Red cell distribution width as a novel prognostic marker in heart failure: data from the CHARM Program and the Duke Databank. J Am Coll Cardiol 2007; 50: 40-7.

14. Seyhan EC, Özgül MA, Tutar N, Ömür I, Uysal A, Altin S. Red blood cell distribution and survival in patients with chronic obstructive pulmonary disease. COPD 2013; 10: 416-24.

15. Seretis C, Seretis F, Lagoudianakis E, Gemenetzis G, Salemis NS. Is red cell distribution width a novel biomarker of breast cancer activity? Data from a pilot study. J Clin Med Res 2013; 5: 121-6.

16. Spell DW, Jones DV Jr, Harper WF, David Bessman J. The value of a complete blood count in predicting cancer of the colon. Cancer Detect Prev 2004; 28: 37-42.

17. Beyazit Y, Kekilli M, Ibis M, et al. Can red cell distribution width help to discriminate benign from malignant biliary obstruction? A retrospective single center analysis. Hepatogastroenterology 2012; 59: 1469-73.

18. Lee H, Kong SY, Sohn JY, Shim H, Youn HS, Lee S, Kim HJ, Eom HS, Elevated red blood cell distribution width as a simple prognostic factor in patients with symptomatic multiple myeloma. Biomed Res Int 2014; 2014: 145619.

\section{Address for correspondence}

\section{F. Tugba Kos}

Department of Medical Oncology

Faculty of Medicine

Duzce University

81000 Duzce, Turkey

e-mail: tugbasan@yahoo.com

Submitted: 7.11 .2014

Accepted: $\quad 20.07 .2015$ 